\title{
The Participation of Africa in the General Agreement on Tariffs and Trade (GATT)
}

\author{
By Wolfgang Benedek
}

\section{The Relevance of GATT for Africa*}

A more active participation of Africa in GATT can be suggested for a number of reasons. First, there is the growing importance of that treaty, which in practice has become an international organization, for any country concerned with international trade. GATT has developed and grown into a complex corpus of international legal instruments which are relevant for all states involved in international trade, thus also the African states.

Second, the nature of GATT law and its evolution is of particular interest for international law in general and international economic law in particular as it contains all problems encountered in international legal doctrine in a nutshell. Its legal basis being only a protocol of provisional application ${ }^{1}$ it has developed a pragmatic and flexible approach to international trade issues. The GATT is a major example of operation of international law in general and the development of international economic law in particular. It is to be expected that African states, which so far have largely neglected GATT rules, in the future will develop a stronger interest in GATT and contribute to its progressive development. ${ }^{2}$

Third, the basic rules and procedures used in GATT are quite close to what one could call the "African approach to international law", namely the practice of consensus and the emphasis on conciliation in dispute settlement. Whereas the complexities of GATT, its restrictive approach and the predominance of the large trading nations have discouraged lawyers from developing countries to give more attention to GATT, today there is reason for fresh scholarly interest because of the enlarged role of GATT which has developed from a forum of tariff negotiations of a few countries into an organization for

* This article is based on my contribution to the Workshop on Teaching and Research in International Law in Africa, Dakar, 11-13 December 1985.

I The Protocol of Provisional Application of GATT entered into force on 1 January 1948. It is contained together with the text of the General Agreement in GATT. Basic Instruments and Selected Documents (BISD), Vol. IV, Geneva 1969. Later accessions normally took place under specific accession protocols.

2 See K. Ginther, The New International Order, A frican Regionalism and Subregional Attempts at Economic Liberation, in: K. Ginther/W. Benedek (Eds.), New Perspectives and Conceptions of International Law, An Afro-European Dialogue, Springer, Vienna 1983, pp. 59 ff. at p. 61. 
the negotiation of the legal framework of international trade, encompassing, with its 91 members, ${ }^{3}$ the major part of international trade.

\section{The Lagos Plan of Action and African Practice}

African states have repeatedly committed themselves to active participation in the elaboration of the framework and rules of international trade. The Lagos Plan of Action, adopted by the Second Extra-Ordinary Assembly of African Heads of State and Government in 1980, in Para. 256 (a) requires OAU member states to "urgently act to increase their effective participation in international economic negotiations". Para. 251 (d) asks for "measures to set up a new trading framework at the international level including agreement on new trading rules and principles" covering in particular structural adjustment, preferential treatment for developing countries and elimination of (neo-)protectionist measures. Generally, Para. 251 stipulates that "measures should be taken to diversify, both geographically and structurally, Africa's present trade patterns". In the light of the present economic crises of Africa, ${ }^{4}$ these objectives have only gained in their importance.

Active participation of African states in the discussions on the international framework for trade appears all the more called for as developments in the international economic environment are being judged to be "particularly unfavourable to African countries". The improvement of the framework conditions for African trade have to be considered to be of first importance to solving the economic crises of the continent. This was also confirmed by the analysis of the Vice-president of the EEC-Commission, M. Natali in his address to the Special Session of the UN General Assembly devoted to the critical economic situation in Africa and held from 27 May to 1 June 1986 in New York: "Le succès de l'aide à l'Afrique dépend de l'amélioration de l'environnement économique international. ${ }^{6}$

Against the argument that this refers mainly to the prices of primary commodities, where a new deterioration of the terms of trade can be observed, it has to be held that African states do not unterstand themselves just as suppliers of raw materials for all times. On the contrary, they rightly aim at a larger share in manufactured products, which so far only constitute some $3 \%$ of their exports. It is by industrialisation that Africa hopes to achieve the necessary diversification of its trade patterns, both with the North and with

3 The main non-member is the Sowjet-Union, whereas China, which was an original member, is just negotiating for its return to GATT-membership: siehe GATT Activities 1985, Geneva 1986.

4 See for example T. Rose (ed.), Crises and Recovery in Sub-Saharan Africa, OECD Paris 1985 and The World Bank, Towards Sustained Development in Sub-Saharan Africa, Washington 1984 or Financing Adjustment with Growth in Sub-Saharan Africa, 1986-90, World Bank 1986.

5 African Intergovernmental Group of Experts Meeting on Trade and Development, Brazzaville, 21-25 October 1985, UN-Doc. E/ECA/TRADE/26 of 26 August 1985, para. 44.

6 Euro-Dialogue $10 / 86$ of 27 June 1986. 
the South. For this purpose Africa will for a long time need market access under preferential conditions. While the Lomé Agreement constitutes a legal framework which takes this need into account, diversification would also mean to develop the markets outside EEC-countries, namely the countries of the European Free Trade Association, the United States and Canada, Australia, New Zealand or the Asian states. For all these markets GATT constitutes the relevant framework for trade.

Therefore, African trade experts are right to conclude that "the future of Africa's trade depends to a large extent on the perceptions of the African policy makers and on their negotiating capacity and skills in any new round of negotiations".?

\section{African Participation in GATT}

African states still show a low profile in international trade negotiations, as can be seen in GATT where only a handful of African countries can be said to show some involvement. But, in the membership of GATT, African states constitute a numerically important group with 28 out of 91 full members, 12 more de-facto members and one provisional member. However, only 12 African countries are represented among the 69 members of the GATT Council, the main organ of GATT. Only 8 out of the 41 have signed any of the Tokyo Round Agreements of $1979 .{ }^{8}$

De-facto members of GATT are countries, to the territory of which the GATT rules have been applied before decolonisation and which, after independence, maintain a de facto application of these rules pending a final decision as to their future commercial policy. ${ }^{9}$ This status allows the country concerned to benefit from most-favoured-nation treatment, without being itself obliged to enter into any new commitments. However, de-facto members do not participate in the activities of GATT. In practice this status, which was meant only for an interim period, has been prolonged again and again and developed into a quasi-permanent status.

The so-called MTN-agreements, which resulted from the Tokyo Round of multilateral trade negotiations like the Code on Technical Barriers to Trade, the Anti-dumping Code, the Subsidies and Countervailing Duties Code or the Arrangement regarding Bovine Meat contain numerous provisions in favour of developing countries. ${ }^{10}$ Therefore, it seems that African states have not acceded to these codes for reasons of interest only, but also because of their lack of legal capacity of assessment and translation of

7 See supra, note 5, para. 45.

8 GATT Activities 1985, p. $74 \mathrm{f}$.

9 Ibid., p. 73, see also BISD, 9th Suppl. (1963), p. 16 (9S/16) and 15S/64 as well as J. H. Jackson, World Trade and the Law of GATT, Bobbs-Merrill, Indianapolis 1969, p. 96 ff. and O. Long, Law and its Limitations in the GATT Multilateral Trade System, M. Nijhoff, Dordrecht 1985, p. 40.

10 Compare the Report by the Director-General of GATT on: "The Tokyo Round of Multilateral Trade Negotiations", Vols I and II, GATT 1979-3 and 1980-1. For the text see BISD 265, 3-196. 
these codes into their national legislations. However, this is held against them by industrialized countries as lack of commitment and legal discipline.

A lack of legal discipline on behalf of GATT can also be found in other areas. Unlike other regions and contrary to their obligations under Article XXIV: (7) of GATT, African contracting parties have not notified GATT of any of the existing customs unions or free-trade areas within Africa to allow for an examination by the usual working party procedure. The exception which proves the rule is the Central African Economic and Customs Union. ${ }^{11}$ One could imagine that this was due to a variety of factors like inability of staff, disregard of the GATT provisions and lack of interest also from the side of GATT itself, the contracting parties of which seemed not all concerned about this fact because of the limited trade impact. In the meantime, this practice has been legalized by the decision of the CONTRACTING PARTIES of 28 November 1979 on "differential and more favourable treatment, reciprocity and fuller participation of developing countries", the so-called "enabling clause", which under Paragraph 2 (c) exempts "regional and global arrangements entered into amongst less-developed contracting parties" for the reduction of tariff and, under conditions to be prescribed by GATT, also non-tariff measures on products exchanged from the requirement of most-favourednation treatment of Art. I of GATT. As result of this provision the rigid criteria of Art. XXIV do not apply any more for customs-unions, free-trade agreements and other regional or global arrangements of developing countries, which have only the procedural obligation to notify such arrangements to GATT. This constitutes a major legal development in GATT law in recognition of the special needs of developing countries.

Generally, there is little practice of African states with regard to GATT. The Protocol of Trade Negotiations among Developing Countries, which was brought into being within the framework of GATT as an initiative of non-aligned states in 1971 has Egypt as its on'y African member. African countries have been most hesitant to engage into meaningful concessions. Hence, Nigeria has been blamed for showing its lack of commitment by having entered only into one concession in its schedule, namely on stock fish. ${ }^{12}$

The only waiver request known is by Malawi in the 60s. ${ }^{13}$ Malawi appears also to be the only African GATT member which has ever used the conciliation procedure of GATT in a case against the United States dealt with under Art. XXII: $2 .{ }^{14}$

With regard to import restrictions because of balance-of-payments difficulties only three African contracting parties have applied the relevant GATT-procedure of Art. XVIII: B, namely Ghana, Egypt and, recently, Nigeria. It is difficult to imagine

11 Compare GATT, BISD, $12 \mathrm{~S} / 73 \mathrm{ff}$.

12 F. Roessler, The Scope, Limits and Function of the GATT Legal System, Working Paper prepared for the so-called "Leutwiler report", commissioned by GATT in 1984 and published as "Trade Policies for a Better Future, Geneva 1985. The paper vas published in: The World Economy, Vol. 8 (1985) 3, 287-298.

13 BISD, 15S/89 und 193, 16S/27 and $17 \mathrm{~S} / 156$ and 162 .

14 United States Subsidy on Unmanufactured Tobacco, see the Report of the GATT Working Party in BISD, $15 \mathrm{~S} / 116 \mathrm{ff}$. 
that other African members did not apply such measures, but obviously without using proper GATT procedures. The practice of Art. XIX, the safeguards clause of the GATT, shows a similar picture. Only in one case (Nigeria) has the safeguards clause ever been used by an independent African country.

This leads to the conclusion that African countries have generally been lax in complying with their procedural obligations in GATT, which does not mean, however, that they can equally be blamed for disregard of their substantive commitments. It seems that African contracting parties by and large abide by the basic GATT principles and rules in their trade policies, such as the most-favoured-nation clause and the principle of non-discrimination. But they do rely on the spirit and the letter of the different provisions of Article XVIII and Part IV of GATT as well as others like the GATT enabling clause, which authorize substantial exceptions, non-reciprocity and preferential and differential treatment. The pragmatic and flexible approach of GATT traditionally pays more attention to substance than to procedure which can also be seen from the fact that the lack of procedural compliance of African countries has not been criticized too much in GATT bodies.

Finally, African countries are particulary reliant on the services regarding trade promotion of the International Trade Centre, which is administered jointly by UNCTAD and GATT, and on technical assistance by the Technical Cooperation Division of GATT, which is mainly directed towards familiarizing of ficials from developing countries with the principles and rules of GATT as a basis for improved participation. For this purpose the Training Division of GATT organizes two so-called "trade policy courses" per year for civil servants from developing countries who get a solid introduction to the structure and functioning of the system of GATT. Since 1955, the regular training courses have been attended by 298 of ficials from 44 African countries and regional organisations. ${ }^{15}$ It is an open question why those functionaries who are better educated in GATT matters than many of their European counterparts do not have more impact in their respective administrations to more effectively serve themselves of the instruments of GATT and participate in GATT activities.

\section{GATT and the NIEO}

Whereas the Havana Charter for an International Trade Organization did take account of the special needs of developing countries, its Chapter III on "economic development and reconstruction" and Chapter VI on "inter-governmental commodity agreements" did

15 I am indebted to T. Konaté, Director of the Technical Cooperation Division of GATT for this and other relevant information and comments on an earlier draft of this article. An overview of the activities of the Technical Cooperation Division of GATT, which also include numerous seminars with government of ficials in developing countries is contained in a recently published leaflet of GATT entitled "Technical Co-operation with Developing Countries". 
not find adequate reflection in the articles of GATT. However, in the following years the trade problems of developing countries led to some important adaptations of the text of the General Agreement. In 1955, Art. XVIII on "governmental assistance to economic development and reconstruction" was totally rephrased to better accomodate the idea of economic development:

"The general concept of the new Article is that economic development is consistent with the objectives of the General Agreement and that the raising of the general standard of living of the underdeveloped countries which should be the result of economic development will facilitate the attainment of the objectives of the Agreement. "16

However, the exceptions for developing countries in the very complex Article XVIII did not prove sufficient, in particular for the export trade needs of developing countries. In 1957 the CONTRACTING PARTIES commissioned a report of a panel of experts on past and current trends in international trade. This "Haberler Report" of 1958 ended with the following general conclusion which in the African context seems to be still valid today: "The under-developed primary producing countries have an interest in obtaining from the highly industrialized countries aid and easier access to markets for their exports. The highly industrialized countries have an interest in the effects upon trade of these economic development policies of the underdeveloped primary producing countries. The only chance of a successful outcome is a negotiated settlement involving a gradual shift away from undesirable policies on both sides. 417

The report led to the establishment of different committees, one of which Committee III was responsible to look into nobstacles to the expansion of trade, with particular reference to the importance of maintaining and expanding the export earnings of the less developed countries $"{ }^{18}$ The objective of expansion of trade of developing countries was also the focus of different declarations of developing countries and GATT ministers ${ }^{19}$ which resulted in the endorsement by a ministerial meeting in 1963 of a programme of action, proposed by GATT developing countries as Part I of its conclusions, containing the objective of free access to markets of industrialized countries for tropical products and various types of action to further the trade and development of less developed countries. ${ }^{20}$ Furthermore, a Committee on the Legal and Institutional Framework of GATT in Relation to Less-developed Countries was established to work out a draft Chapter on Trade and Development, which became Part IV on Trade and Development, adopted by a special session of the CONTRACTING PARTIES in November 1964. Part IV contains Articles XXXVI to XXXVIII which deal with principles and objectives, commitments and joint action. These titles, however, are overstatements in

16 Analytical Index, Article XVIII - 1 and BISD, 3S/179 ff. Comp. Havana Charter, Art. 8, 12 and 13.

17 Trends in International Trade, A Report by a Panel of Experts, GATT, Geneva 1958, Para. 350.

18 BISD 7S/28; see also Jackson, supra note 9, pp. $640 \mathrm{ff}$.

19 See for example the declaration of ministers of 7 december 1961 on the promotion of the trade of less-developed countries, BISD, $10 \mathrm{~S} / 28 \mathrm{ff}$.

20 I. Measures for the Expansion of Trade of Developing Countries as a Means of Furthering their Economic Development, BISD, 12S/36 ff. and $44 \mathrm{ff}$. 
view of the fact that they mainly contain programmatic provisions, which by some are not considered as forming part of the "hard law" of GATT, with the exception of Article XXXVI: 8 which contains the principle of non-reciprocity in trade negotiations. The exact meaning of this provision is explained in a note annexed: thus, "less-developed contracting parties should not be expected, in the course of trade negotiations, to make contributions which are inconsistent with their individual development, financial and trade needs". Part IV came into force on 27 June 1966 for the countries which had accepted it, but could also be applied already earlier through a "declaration on de facto implementation". It should be noted in this context that among the last contracting parties to accept Part IV was Senegal (1975) and France (1978)! ${ }^{21}$

The fact that the UN Conference on Trade and Development (UNCTAD) had taken place in Geneva from March to June 1964 and was to be established as a permanent institution by the UN General Assembly certainly had its effect on developments in GATT which, however, proved unable to accomodate the interests and needs of developing countries in a satisfactory way within its own legal framework. The consequences are well known: UNCTAD was created as an alternative institutional approach to trade and development. GATT and UNCTAD developed in different ways, sometimes on rival terms. Only since the mid-80s is there a clear convergence of views to be observed, which reflects a new realism in UNCTAD, after having gone through a series of crises. ${ }^{22}$ One important institutional outcome of Part IV was the creation of the Committee on Trade and Development as a permanent body of GATT, responsible for reviewing the implementation of Part IV. The Committee dealt with almost all aspects of interest to developing countries. ${ }^{23}$ In 1980, two sub-committees were created, one on the least-developed countries and another on protective measures.

Part IV did not authorize trade preferences for developing countries although preferences for less-developed countries and among less-developed countries on a selective product basis had already formed part of the proposals of the Ministerial Meeting of May 1963. ${ }^{24}$ The quest for a Generalized System of Preferences by Resolution 21 of UNCT AD II was responded to by GATT in the form of a waiver procedure under Art. XXV: 5 of the General Agreement which permitted developed contracting parties to disregard the most-favoured-nation clause of Art. I to accord preferential tariff treatment to products from developing countries for ten years. ${ }^{25}$ At the opening of the Tokyo Round of Multilateral Trade Negotiations in 1973 the Ministers issued a declaration according to which the objectives of the Tokyo Round included, inter alia, "a substantial improvement in the conditions of access for the products of interest to the

21 See BISD, 13S/10 and Status of Legal Instruments, GATT, LEG/1, No. 96.

22 See for example R. Ramsay, UNCTAD's failures: the rich get richer, in: International Organization, Vol 38 (1984), S. 387-397.

23 See Activities of the Committee on Trade and Development, GATT-Doc. TC(82) 189 of December 1982.

24 BISD, $12 \mathrm{~S} / 44$, para. 24.

25 Compare A. Yusuf, Legal Aspects of Trade Preference for Developing States, A Study on the Influence of Development Needs on the Evolution of International Law, Nijhoff, The Hague 1982, pp. $87 \mathrm{ff}$. 
developing countries and, whenever appropriate, measures designed to attain stable, equitable and remunerative prices for primary products «. ${ }^{26}$ During the negotiations a so-called "framework group" was entrusted with the task to elaborate appropriate texts to accomodate the needs of the developing countries. But only in 1979, at the end of the Tokyo Round, the CONTRACTING PARTIES adopted a decision on differential and more favourable treatment, reciprocity and fuller participation of developing countries", the so-called "Enabling Clause", which finally provides a general legal basis for the Generalized System of Preferences, for regional and global cooperation among LDC's and special treatment of least developed countries.

In addition, a special footnote allows for considering won an ad hoc basis under the GATT provisions for joint action any proposals for differential and more favourable treatment" not covered by the general clause. This footnote has gained some importance as a legal basis both for the SPARTECA agreement in the South Pacific and the unilateral Caribbean Basin Economic Recovery Act of the United States in favour of a number of Caribbean beneficiaries. ${ }^{27}$

\section{V. "Graduation" and African countries}

One author, in a comparison of the trade policy recommendations of the "Charter of Economic Rights and Duties of States" (UNGA-Res. 3281 (XXIX) of 1974) with GATT law has come to the conclusion that most trade policy principles contained in this Charter have already been incorporated in GATT law. ${ }^{28}$ None-the-less, this and other authors ${ }^{29}$ claim that developing countries in total benefit little from the different exemptions and preferences in their favour, because they constitute a disincentive to developing countries' governments to pursue economically efficient trade policies, whereas they contribute to a general erosion of the multilateral trading rules, which constitute a shield of protection for those countries. This leads to the assumption of an unfavourable "linkage" between the "positive discrimination" for the benefit of developing countries and the "negative discrimination" with which developing countries increasingly are confronted in form of neo-protectionist measures of all kinds. Furthermore, the report of seven eminent persons under the chairmanship of the Swiss banker Leutwiler found that

26 BISD, 20S/20.

27 See BISD, 265/203 and W. Benedek, The Caribbean Basin Economic Recovery Act: A New Type of Preferences in GATT?, Journal of World Trade Law, Vol. 20 (1986) 1, pp. 29-46.

28 E. U. Petersmann, International Trade Order and International Trade Law, Economic and legal issues of integrating developing countries into the multilateral trading system, paper presented to the International Law Association's Committee on Legal Aspects of a New International Economic Order, see the report of this Committee to the ILA-conference in Seoul 1986, 29-31.

29 See also R. E. Hudec, The Participation of Developing Countries in the GATT Legal System, Trade Policy Research Centre, London 1987. 
the measures in favour of developing countries have served them little, they should better concentrate on exchanging concessions. ${ }^{30}$

Two kinds of comments have to be made to this sort of reasoning. First, it would be a dangerous approach to create the impression that there are hard rules concerning concessions and soft rules as regards the treatment of developing countries on the basis of non-reciprocity. Second, developing countries in general will forquite some time not be able to negotiate on an equal footing; they will have to rely on the GATT rules allowing for exceptions and more favourable treatment.

It is an undue exaggeration to blame developing countries having received recognition of their particular status and development needs for the erosion of the international trading order. The major exceptions from GATT rules which, in addition, are of particular disadvantage to the developing countries date back to the 50 s, i. e. the waiver allowing U.S. import restrictions on agricultural products of 1955 and the 60 s, i. e. the cotton-textiles arrangement of 1961 which later became the Multifibre Arrangement and was prolonged in 1986 in a more restrictive version - in spite of all promises of liberalisation. In addition most VERs and OMAs are negotiated with LDCs to limit their exports. Therefore, it is no surprise when a recent study by G. C. Hufbauer and J. J. Schott presents the particular interest of LDCs in the new round simply as getting the U.S. and Europe to respect their GATT obligations and eliminate trade barriers inconsistent with GATT. ${ }^{31}$

On the other side, it cannot be disregarded that there are growing differences of economic level and competitivity among developing countries themselves. The General System of Preferences, although most developed countries do already use differentiated schemes, is being exploited by a handful of newly industrialized developing countries, whereas other developing countries are not able to benefit from it in the same measure. The GATT Enabling Clause has already taken account of this problem by providing in Para. 7 that:

"Less-developed contracting parties expect that their capacity to make contributions or negotiated concessions or take other mutually agreed action under the provisions and procedures of the General Agreement would improve with the progressive development of their economies and improvement in their trade situation and they would accordingly expect to participate more fully in the framework of rights and obligations under the General Agreement."

What is expressed here in terms of "participation" is called the principle of "graduation". But is does not contain any specific rule of graduation. In general, newly industrialized developing countries (NICs) may gain competitivity in some sectors but not in their economy as a whole. Therefore, they still require preferential treatment although

30 Trade Policies for a Better Future - Proposals for Action, GATT Geneva 1985, p. 44 f.

31 See G. C. Hufbauer/J. J. Schott, Trading for Growth: The Next Round of Trade Negotiations, Institute for International Economics, Washington 1985, p. 2. 
not in all sectors. But there is no agreement whatsoever when the conditions for graduation are reached. In reaction to increasing pressures form their own producers the United States has unilaterally graduated out a number of products of newly industrialized countries like Hongkong, South Korea and Taiwan applying certain criteria of competitive need. ${ }^{32}$

For developing countries which have not reached a higher level of economic development, which means for almost all African countries, graduation is not to be expected in the near future. The graduation of the NICs may, in principle, improve the value of the $G S P$ for them.

Special treatment for least developed countries is also a well established principle of the GATT Enabling Clause. The basic idea behind is the principle of substantive equality which, according to the $I L A$ "declaration on the progressive development of principles of public international law relating to a NIEO", adopted in Seoul in 1986, justifies preferential and non-reciprocal treatment of and among developing countries, nin view of their differentiated needs of development."133 There are considerations of equity, fairness and justice which require that developing countries are treated according to their needs and abilities. Developing countries' solidarity should not stand in the way of such a differentiated approach.

In addition to this kind of graduation by "graduating out" certain products and countries from particular (GSP) benefits, there is also another form of graduation, which I would like to call "indirect graduation". Indirect graduation works the other way round: by granting special advantages to particular countries or groups of countries the other developing countries stay behind, they are put on a lower level of favourable treatment. The most common form of indirect graduation is the special treatment of least developed countries. However, there are numerous other forms of special advantages for particular groups of developing countries, as in the case of the Caribbean Basin Initiative and, in particular, in the case of the Lomé Agreement, of which the black African states are the main beneficiaries. Although the Lomé Convention in Art. 1 pledges to constitute a model for the economic relations between developed and developing states and, in fact, reaches a high standard in terms of the international law of development ${ }^{34}$ the EEC has never accorded the same treatment to other (groups of) developing countries. Therefore, Lomé constitutes a case of indirect graduation, which is legitimate in view of the fact that almost all ACP-states belong to the low-income developing countries. However, the Lomé agreement as an interregional cooperation agreement together with

32 See for example I. Frank, The "Graduation" Issue for LDCs, in: Journal of World Trade Law, Vol 13 (1979), pp. 289 ff., at 295 ff. R.I. Meltzer, The U.S. Renewal of the GSP, in: JWTL, Vol. 20 (1986) 5, 507-525.

33 For a comparison of the ILA-draft with a similar project by UNITAR see W. Benedek, Progressive Development of the Principles and Norms of International Law Relating to the NIEO - The UNITAR Exercise, in: Austrian Journal of Public and International Law, Vol 36 (1985) 4, pp. 298-328. For the "Seoul Declaration" see Netherlands International Law Review, Vol. 33 (1986), 326-333.

34 See G. Feuer/H. Cassan, Droit international du développement, Paris 1985 and W. Benedek, The Lomé Convention and the International Law of Development: A Concretization of the New International Economic Order? in: Journal of African Law, Vol. 26 (1982) 1, p. 74-93. 
numerous other cooperation agreements of the EEC with developing countries has also led to a fragmentation of the international trade regime which today has to be reviewed for its negative consequences for the multilateral trade order.

Differentiation in preferential treatment raises the question of non-discrimination in international trade. The principle of non-discrimination is one of the cornerstones of the multilateral trade order of GATT. The unconditional most-favoured-nation clause of GATT, Art. I, is based on that principle. But, already with regard to the Tokio Round Codes the United States have used discriminatory measures to force developing countries to sign that codes. In the forthcoming new round of negotiations there is a danger that a conditional MFN-clause is being applied to force the NICs to make adequate concessions, both in material terms and with regard to the legal framework of GATT. These are negative consequences of the growing fragmentation in the international trade regime. Therefore, the principle of elimination of discriminatory treatment in international commerce as contained in the law of GATT to be realized on a multilateral basis today may gain new significance. It is becoming more and more a shield of protection of LDC's against bilateral pressures for special arrangements and a means towards securing market access.

It is the task of the lawyer to reconcile the principles of differential treatment and of non-discrimination. GATT law itself provides the clue. To take up the distinction in a book by an experienced GATT staff member, we have to distinguish between non-discrimination erga omnes and non-discrimination inter partes. ${ }^{35}$ The principle of non-discrimination erga omnes is the general rule. Exceptions from it have to be based on legitimate grounds, namely on special rules of GATT, like the GATT Enabling Clause, which takes account of the principle of non-discrimination inter partes. Discrimination not covered by such legal authorization constitutes a violation of GATT law.

\section{The New Challenge}

With regard to trade the Lomé Agreement has shown that, although it constitutes a comprehensive legal approach, it also is of a limited nature. For example, during Lomé II the ACP exports to the EEC have fallen significantly, whereas to other destinations ACP countries could even enlarge their share. In spite of this fact, ACP states did not reach any substantial improvement with regard to market access in the negotiations on the chapter on trade cooperation of Lomé III. ${ }^{36}$ In conclusion, African states are well

35 J. Nussbaumer, L'Enjeu du Dialogue Nord-Sud: Partage des Richesses ou Guerre Economique, Paris 1980, p. 116.

36 See on the trade ACP: EEC the dossier in Le Courier, No. 98 (1986), pp. 61-91, esp. p. 65 and 67. See also J. Huber, From Lomé II to Lomé III: Improvements and New Features in the Third ACP-EEC Convention signed on 8 December 1984, in: Legal Issues of European Integration 1985/1, pp. 1-26, esp. pp. 8 ff. and generally M. Subhan, The EEC's Trade Relations will the Developing Countries, Europe Information Development, $\mathrm{X} / 42 / 85$. 
advised not to satisfy themselves with the trade opportunities of the Lomé Agreement but also to take advantage of their rights under the multilateral trading order of GATT. Given the fact that the preferential access provisions in the ACP - EEC convention are limited to five years it seems worth considering if African states should not try to seek improved access for some of their products even in the EEC by negotiating for reductions and bindings of tariffs on a MFN basis, in particular in cases where the margins of the special preferences enjoyed by ACP states are insignificant. Another major concern of African states could be negotiations to reduce existing tariff escalations, which constitute disincentives to the exports of processed goods both to the EEC and elsewhere.

Today, preparations have started for a new round of multilateral trade negotiations, the so-called Uruguay-Round, which offers itself as a special opportunity to address the interests of African states.

GATT constitutes the only forum for real negotiations on the international framework for trade. There are two main reasons for LDC's including African countries, to participate actively in these negotiations. First, negotiations will result in a package approach, in which LDC's are better able to incorporate their special interests. Second, the problems in international trade law cannot be perceived any more on North-South lines alone. Since the emergence of the debt crises in particular one can observe a new convergence of interests between developed and developing countries. What could be taken for granted 10 years ago, namely the existence of a rule-oriented multilateral regime for international trade, today is subject to erosion, and a growing grey area of non-tariff protectionist measures affects developing countries as well as industrialized countries, in particular the small ones. Market access - the main interest of LDC's in international trade - today more than ever is endangered by the practices of the new protectionism like Voluntary Export Restraints and Orderly Marketing Agreements. But overcoming the new protectionism and assuring market access is also a prerequisite for the repayment of debts and thus a solution of the debt crises ${ }^{37} \mathrm{~A}$ new effort to reach a "standstill" and "roll back" of these measures is attempted in the new round. This problem is regarded both in UNCTAD and in GATT as the main problem of present international trade relations but it is mainly in GATT where real remedies can be found. For some developing countries the disadvantages of negative discrimination, which is against the spirit if not the letter of GATT may already outweigh the benefits from positive discrimination, i. e. preferential treatment. For this purpose, it will be necessary that African countries clarify their priorities with regard to their problems and interests to be pursued in the new GATT round as early as possible. A lot of groundwork has been done since the Tokyo Round, in particular by the Committee on Trade and Development of GATT which has undertaken numerous consultations on the operation of the Enabling Clause, on the needs of particular least developed countries and, in 1984, produced a study on

37 R. H. Green, Access for Exports, the New Protectionism and all GATT: Notes Towards Negotiable Proposal, mimeo; see also K. Jae-Ik, Need for Developing Countries to Play their Role in GATT, in: The World Economy, Vol. 6 (1983)3, p. $245 \mathrm{ff}$. 
"Prospects for Increasing Trade Between Developed and Developing Countries. ${ }^{38}$ Analyses of the Tokyo Round negotiations have led to the conclusion that "the codes could have been more favourable to the developing countries had they more effectively participated in the negotiations" ${ }^{39}$

Among the topics agreed upon by the GATT Ministerial Conference of Punta del Este ${ }^{40}$ which might be of particular interest to African countries are tariff graduation for processed goods, agricultural trade, textils, tropical products, natural resource-based products, including processed goods therefrom and, generally, the strengthening of GATT rules, in particular with regard to all forms of neo-protectionism. Another issue of special interest to African countries, which has been present in GATT from very early on concerns the persistent decline of commodity prices. African countries are further concerned with the exports of domestically prohibited goods into their markets. These are products like pharmaceuticals, fertilizers, insecticides etc. which are prohibited to be sold in the domestic markets of the producing countries because of the risk they constitute for the health of the human and animal populations as well as the natural environment. In this respect international control measures are to be sought and GATT could constitute a forum for this purpose. The new round of multilateral trade negotiations, opened by the conference of ministers in Punta del Este in September 1986, will also have to take up some unfinished issues of the Tokyo Round, of which the question of a code on safeguard measures in interpretation of Article XIX of the General Agreement is also of primordial interest to LDCs. ${ }^{41}$

The Ministerial Declaration of 29 November 1982, which set out a work programme including, in a special annex, issues of particular concern to developing countries ${ }^{42}$ has proved unable to achieve the desired objectives without a major effort, such as the new round. The complex issue of services, which had delayed agreement on a new round because of the opposition of some LDCs seems not to create a major problem for the African countries at present. ${ }^{43}$

This time free-rider benefits cannot be taken for granted for LDCs any more. A kind of open graduation is being aimed at by industrialized countries, which means, that LDCs should make adequate contributions, according to their state of development. ${ }^{44}$ African

38 GATT Doc. Spec (84) 21; See the yearly reports of the Committee in BISD, i.e. $32 \mathrm{~S}$, (1986), pp. $22 \mathrm{ff}$.

39 B. Balassa, The Tokyo Round and the Developing Countries, JWTL, Vol. 14 (1980) 2, 93 ff., at 118 and T. E. Ibrahim, Developing Countries and the Tokyo Round, JWTL, Vol. 12 (1978) 1, 1-26.

40 See Ministerial Declaration on the Uruguay Round, GATT/1396 of 25 September 1986.

41 See I. Frank, Trade Policy Issues of Interest to the Third World, Thames Essay No. 29, London 1981, pp. $21 \mathrm{ff}$.

42 BISD, 29 S (1983), pp. 22 f., see also GATT Focus, No. 18 of Dec. 1982.

43 The opposition against integrating services in the new round stems mainly from India and Brazil which would have prefered to see the objectives of the work programm achieved first; compare the statement of India on behalf of the delegations of 24 developing countries in the GATT Council on nimprovement of world trade relations", GATT Doc. L/5818 of 7 June 1985 and L/5818/Add. 1. See also J. J. Schott and J. Mazza, Trade in Services and Developing Countries, JWTL, Vol. 20 (1986) 3, $253 \mathrm{ff}$.

44 Neue Zürcher Zeitung, No. 167 of 23 July 1986, p. 9 f. and GATT Focus, No. 40 (July/August 1986). 
countries certainly will be the last to be expected to make large contributions, but to show their commitment by some kind of contribution will be highly appreciated. This could take the form of tariff concessions or of legal commitments, like signing some of the GATT codes. Although not being affected in the first place African states should further be concerned with the elaboration of general criteria and conditions for guidelines on fuller participation in the framework of GATT rights and obligations by developing countries if such an approach becomes feasible at all. Generally, African GATT member states, of which a number have accepted even supervision by the International Monetary Fund, should not find it too demanding to commit themselves to larger participation in the GATT framework in general. For the 12 de facto-members, they might consider taking that opportunity to accede fully to GATT, which could strengthen the African group. The services of ECA and other competent institutions should be commissioned to assist in developing adequate strategies to translate the objectives spelled out in particular in the Lagos Plan of Action into an African Common strategy to the negotiations in the new round of GATT.

The new GATT round therefore asks for the active participation of developing countries, and African countries should not miss that opportunity to pursue their interests. 


\title{
ABSTRACTS
}

\section{Regional Economic Co-operation in Developing Countries}

\author{
By M. L. Marasinghe
}

The article focuses on the need and the importance of establishing regional national groupings for the purposes of National Economic development. The thinking towards regional economic integration was indeed a result of a conviction that third world countries are hampered from being developed by overwhelming economic advantages held by the developed nations. The early attempts for economic integration was found in Africa. There were many attempts and these have grossly failed due to political and social tensions arising within them. The East African Community which included: Kenya, Tanzania and Uganda - ended as a result of Idi Amin's seizure of power in Uganda in 1971. The only Regional group that now effectively exists in Africa is the E.C.O.W.A.S. - the Economic Community of West African States - a union that is formed out of both Anglo-phonic and Franco-phonic Africa. This too does not provide an appreciable economic growth. The fortunes of many of its members do not provide a consistent growth pattern and this fact appears to have affected the union as a whole. In contrast, as from 1967, the Association of South East Asian Nations (A.S.E.A.N.), with a land mass of 1.2 million square miles, a total population of 264.5 million, per capita income of 1324 U.S. Dollars and a growth rate of over $7.2 \%$, grouped together to form the most successful regional economic grouping \% now after 1984 - with five member states. These are: Singapore, Malaysia, Thailand, Brunei (after 1984), and the Philipines. The paper deals with these reginal groups and with the general notion of regional economic integration.

\section{The Participation of Africa in the GATT}

\section{By Wolfgang Benedek}

African states have on various occasions, as in the Lagos Plan of Action of 1980, committed themselves to active participation in the elaboration of the framework and rules of international trade. An analysis of African participation in GATT, however, shows that African member states have generally been lax in complying with their GATT obligations and in exploiting the opportunities of that instrument which provides for numerous exceptions in favour of developing countries. 
African states are found to focus their interests excessively on the Lomé agreement whereas the GATT provides a set of multilateral rules relevant also to all non-EEC trade. The forthcoming "Uruguay Round" of multilateral trade negotiations, which is to produce new rules in various fields of trade, constitutes a particular challenge for a more active participation of Africa, to prevent the erosion of preferential rules (graduation) and to achieve better conditions of market access worldwide.

\section{Islamization of Banking: What Does It Mean For Agricultural Financing? - The Case of Pakistan}

\section{By Joachim von Stockhausen}

Islamic banking brings many changes in the modes of agricultural financing. It has consequences for the mobilization of rural savings and implications for the character of rural banks.

The Islamic Banking System introduced in Pakistan distinguishes between three groups and twelve modes of financing. The main modes of agricultural financing are interestfree loans, mark-up loans and, exclusively for medium and longterm financing, leasing and hire purchase.

From the middle of 1985, Pakistani banks have not accepted any interest-bearing deposits; savings accounts are only accepted on a profit-and-loss basis. Discussion is controversial with regard to the question of how depositors will react to the abolition of interest. There is a strong body of opinion holding that, for avoiding exploitation of the depositors, a scheme has to be devised which ensures profit within a reasonable range. Trying to conform to Islamic economic doctrine and considering the comparatively high risks of Islamic modes of financing, the banks have lost their character as simple retailers of money and acquired that of partners with greater responsibility for the viability and profitability of the ventures into which they enter. Moreover, to give savers a stronger opportunity to observe what is done with their funds, there is a specific impulse for control of the banks' activities by the depositors. This means that the philosophy of Islamic banking has institutional implications which are in harmony with a stronger participation of the rural population in the development process. At the same time, however, there are some signs which make one sceptical as to whether institutional reforms will really take the direction envisaged. The organizational aspect of a proper balance between borrower, bank and depositor seems to deserve greater attention in order to make banks a real part of rural society. 